\title{
Estimating impact of weather factors on wheat yields by using panel model approach - The case of Serbia
}

\author{
Marko Jelonik, Jovan Zubović, Aleksandar Zdravkovi \\ Institute of Agricultural Economics Belgrade, Volgina 15, Belgrade, 11000, Serbia
}

\section{A R T I C L E I N F O}

JEL classification codes:

Q10

Q19

Q54

\section{Keywords:}

Wheat yield

Evapotranspiration

Sub-period

Altitude

Panel model

\begin{abstract}
A B S T R A C T
In Serbia irrigation is not widely utilized to reduce water scarcity in crop production. Therefore, wheat yields largely depend on weather factors. Over the past two decades, there has been recorded a significant change in weather conditions in Serbia. Such change produces concerns about Serbia's food security and exports since wheat is among the most important agricultural products. In this paper authors analyze and quantify the impact of weather factors on the achieved wheat yields, using a set of panel data on selected Serbian municipalities in fourteen years (2000-2013). The multidimensional regression was conducted as a sort of quasi-experiment, combining data on achieved yields in selected municipalities, with data on weather factors: temperature, precipitation, extraterrestrial radiation, and evapotranspiration. Utilizing the Hargreaves method of determining reference evapotranspiration, average daily water deficit was computed as a single representative indicator of weather conditions. Testing was conducted on four predefined sub-periods within the vegetation season of wheat, and the impact of average daily water deficit on wheat yields was estimated for each of these sub-periods. Results show a robust, statistically significant impact of change in average daily water deficit on decreased wheat yields. Growth of water deficit by $0.1 \mathrm{~mm}$, in the period November 15th to April 1st results with $175 \mathrm{~kg} / \mathrm{ha}$ lower yields, while in the period April 1st to May 15 th results in $45 \mathrm{~kg} /$ ha lower yields. Impact shows to be conditional on the altitude, rapidly losing on intensity and significance above $100 \mathrm{~m}$.
\end{abstract}

\section{Introduction}

Wheat production in Serbia plays an essential role in the development of the food industry and the foreign trade balance of the national agrarian sector, covering nearly $20 \%$ of total arable land (Jelonik et al., 2017). Wheat production is highly dependent on water availability. During the past hundred years, global warming increased the average temperature by $0.8^{\circ} \mathrm{C}$. Projections for further growth are around $2.8^{\circ} \mathrm{C}$ for Britain, $3.8^{\circ} \mathrm{C}$ in Central Europe, and $4-5^{\circ} \mathrm{C}$ in the region of Southern Europe by the end of the 21st century (Ratknić et al., 2017). Change in weather conditions has a direct impact on the sustainability of wheat production.

The paper aimed to evaluate the statistical significance of the impact of weather factors on wheat yields from the aspect of replacing the effects of irrigation, i.e., the adequate presence of water available to plants in the soil.

Research related to the impact of weather factors on agricultural productivity can be divided into processes-based modeling (mathematical expression of one or several processes that characterize the functioning of a biological system of general or economic interest of humanity) and statistical approach (Buck-Sorlin, 2013; Moore et al.,
2017). Variability of weather factors was tested by mathematical statistical models, which most frequently relied on a stochastic approach (Mihailović et al., 2004). In recent years, new models have offered a more detailed analysis of the interaction of the variability of weather factors on yields (Nelson, Shively, 2014).

Establishment of integrated climate models for projections of their impact on the economic activities using harmonizing the values of selected weather parameters collected over a long period was limited by the width of the territory covered and the number of analyzed factors (Stute et al., 2001; Slingo et al., 2009). A high correlation between yields and precipitation or intensity of irrigation has been confirmed in a study on maize (Klocke et al., 2011).

Research carried out on field crops in California (USA), identified the availability of water, soil fertility and the availability of energy as the most essential factors in achieving the potential yields of a crop, from the aspect of the evapotranspiration potential of the soil. The model considered the estimation of the scarcity of available precipitation versus the price of water for irrigation. Where water is not deficient intensifying irrigation is feasible to a level that ensures maximum possible crop yields (Hargreaves, Samani, 1984).

The optimization and sustainable implementation of irrigation

E-mail address: marko_j@iep.bg.ac.rs (M. Jelonik). 
Table 1

Municipalities covered by the sample according to the altitude. Source: Zubović et al., 2017.

\begin{tabular}{llc}
\hline Group & Municipality & $\mathrm{m}$ \\
\hline \multirow{2}{*}{ Up to $100 \mathrm{~m}$} & Negotin & 42 \\
& Zrenjanin & 80 \\
& Kikinda (Čoka) & 81 \\
& Sremska Mitrovica & 81 \\
$100-200 \mathrm{~m}$ & Alibunar (Banatski Karlovac) & 89 \\
& Subotica (Palić) & 102 \\
& Loznica & 121 \\
& Ćuprija & 123 \\
Over $200 \mathrm{~m}$ & Zaječar & 144 \\
& Kragujevac & 200 \\
& Kraljevo & 215 \\
& Leskovac & 230 \\
& Požega & 310 \\
& Vranje & 432
\end{tabular}

measures at the daily level initiated the creation of a smart system (ENORASIS platform), transforms weather, hydrological and land parameters into an adequate decision related to the dynamics and intensity of irrigation in a farm (Chatzikostas et al., 2013; Cannata, Antonović, 2015).

Climate-crops models are mainly oriented towards testing the impact of precipitation and temperature on crop yields. Results in such models show a highly positive correlation of yields with precipitation levels, as well as precipitation distribution and temperature levels (Vidal, Wade, 2009; Lee, Kim, 2013). Spatial differentiation by weather factors, confirms the impact on yield and sustainability of crop production as a result of expansion or intensification of irrigation (Kang et al., 2009; Challinor et al., 2018). Cross-section and time-series research on the impact of precipitation resulted in the classification of areas primarily suitable for crop production (Tozer et al., 2014).

The research conducted in the Netherlands shows that extremely high temperatures and excessive or lack of precipitation are indicated as the leading causes of wheat yields decline (Powell, Reinhard, 2016).

The research of the impact of weather factors on the results of crop production in Serbia has so far been based on long-term experiments with sugar beet (Maksimović, Dragović, 2002), in cultivation of common crops, such as winter wheat, maize, sugar beet, soya beans, sunflower and alfalfa (Maksimović, Dragović, 2004; Dragović, 2012), or soybean production (Pejić et al., 2012; Kresović et al., 2016). Some authors have confirmed the positive impact of irrigation using specialized software packages (Cropsyst, Aquacrop or DSSAT), (Stričević et al., 2014; Kresović et al., 2014). On the other hand, besides mathematical-statistical estimates with a reduced number of parameters, regional distribution and a lower level of methodological complexity, the long-term comparative analyses of the spatial and seasonal effects of weather change on the yields of certain crops have not been yet carried out extensively (Munćan, 2016).

\section{Materials and methods}

The assessment was carried out by analyzing the data panel covering different weather factors, altitude, yields, and share of land under wheat in total utilized agricultural land in selected Serbian municipalities in fourteen years.

The panel represents a multidimensional regression in space and time harmonized with the weather parameters defined by the Hargreaves method of determining reference evapotranspiration $\left(E T_{o}\right)$. The panel covered a sample of 14 selected municipalities (Table 1 ), in the long-term time cross-section. The sample size and the quality of the dispersion of municipalities in Serbia were determined by the extent of wheat distribution, grouping them by altitude and the wheat production intensity.
Table 2

Saturation of soil moisture on the wheat planting day (in \%) and average daily water deficiency (in $\mathrm{mm}$ ) by sub-periods in municipalities up to $100 \mathrm{~m}$. Source: Jelonik, 2017.

\begin{tabular}{|c|c|c|c|c|c|c|}
\hline Year & Variable* & Negotin & Zrenjanin & $\begin{array}{l}\text { Sremska } \\
\text { Mitrovica }\end{array}$ & $\begin{array}{l}\text { Banatski } \\
\text { Karlovac - } \\
\text { Alibunar }\end{array}$ & $\begin{array}{l}\text { Kikinda - } \\
\text { Čoka }\end{array}$ \\
\hline & $\begin{array}{l}\text { Altitude } \\
\text { (in m) }\end{array}$ & 42 & 80 & 81 & 89 & 96 \\
\hline \multirow[t]{5}{*}{2000} & $\mathrm{f}_{0}$ & $22,5 \%$ & $52,0 \%$ & $35,2 \%$ & $53,0 \%$ & $50,8 \%$ \\
\hline & $\mathrm{ff}_{1 \text { avg }}$ & 0,51 & 0,50 & 0,69 & 0,48 & 0,54 \\
\hline & $\mathrm{ff}_{2}$ avg & 0,13 & 0,06 & 0,09 & 0,08 & 0,08 \\
\hline & $\mathrm{ff}_{3 \text { avg }}$ & 1,62 & 1,44 & 1,70 & 1,55 & 1,50 \\
\hline & $\mathrm{ff}_{4}$ avg & 4,25 & 3,94 & 4,43 & 4,22 & 4,25 \\
\hline \multirow[t]{5}{*}{2001} & $\mathrm{f}_{0}$ & $41,2 \%$ & $13,2 \%$ & $28,0 \%$ & $30,4 \%$ & $10,8 \%$ \\
\hline & $\mathrm{ff}_{1 \text { avg }}$ & 0,87 & 1,30 & 1,17 & 1,10 & 1,34 \\
\hline & $\mathrm{ff}_{2}$ avg & 0,35 & 0,47 & 0,25 & 0,53 & 0,51 \\
\hline & $\mathrm{ff}_{3}$ avg & 0,90 & 0,63 & 0,45 & 0,60 & 0,62 \\
\hline & $\mathrm{ff}_{4}$ avg & 2,20 & 1,36 & 0,89 & 1,21 & 1,59 \\
\hline \multirow[t]{5}{*}{2002} & $\mathrm{f}_{0}$ & $47,5 \%$ & $69,1 \%$ & $74,0 \%$ & $76,3 \%$ & $68,3 \%$ \\
\hline & $\mathrm{ff}_{1 \text { avg }}$ & 0,73 & 0,42 & 0,39 & 0,38 & 0,42 \\
\hline & $\mathrm{ff}_{2}$ avg & 0,53 & 0,18 & 0,18 & 0,20 & 0,20 \\
\hline & $\mathrm{ff}_{3}$ avg & 2,12 & 2,08 & 1,75 & 1,93 & 2,02 \\
\hline & $\mathrm{ff}_{4}$ avg & 3,70 & 3,78 & 3,14 & 3,11 & 3,26 \\
\hline \multirow[t]{5}{*}{2003} & $\mathrm{f}_{0}$ & $100,0 \%$ & $70,0 \%$ & $100,0 \%$ & $100,0 \%$ & $60,0 \%$ \\
\hline & $\mathrm{ff}_{1}$ avg & 0,04 & 0,35 & 0,03 & 0,03 & 0,46 \\
\hline & $\mathrm{ff}_{2}$ avg & 0,10 & 0,12 & 0,12 & 0,10 & 0,12 \\
\hline & $\mathrm{ff}_{3}$ avg & 1,13 & 2,02 & 2,30 & 1,95 & 2,03 \\
\hline & $\mathrm{ff}_{4}$ avg & 2,19 & 4,18 & 3,83 & 4,01 & 4,27 \\
\hline \multirow[t]{5}{*}{2004} & $\mathrm{f}_{0}$ & $40,6 \%$ & $66,5 \%$ & $48,3 \%$ & $68,6 \%$ & $76,9 \%$ \\
\hline & $\mathrm{ff}_{1}$ avg & 0,17 & 0,14 & 0,24 & 0,12 & 0,12 \\
\hline & $\mathrm{ff}_{2}$ avg & 0,06 & 0,05 & 0,06 & 0,05 & 0,04 \\
\hline & $\mathrm{ff}_{3}$ avg & 0,94 & 0,56 & 0,54 & 1,07 & 0,45 \\
\hline & $\mathrm{ff}_{4}$ avg & 2,00 & 1,79 & 1,75 & 2,07 & 2,29 \\
\hline \multirow[t]{5}{*}{2005} & $\mathrm{f}_{0}$ & $39,9 \%$ & $63,5 \%$ & $80,0 \%$ & $62,2 \%$ & $57,6 \%$ \\
\hline & $\mathrm{ff}_{1 \text { avg }}$ & 0,58 & 0,40 & 0,12 & 0,52 & 0,50 \\
\hline & $\mathrm{ff}_{2}$ avg & 0,07 & 0,04 & 0,05 & 0,04 & 0,03 \\
\hline & $\mathrm{ff}_{3}$ avg & 0,52 & 0,94 & 0,70 & 0,73 & 0,55 \\
\hline & $\mathrm{ff}_{4}$ avg & 2,23 & 1,94 & 1,54 & 1,85 & 1,62 \\
\hline \multirow[t]{5}{*}{2006} & $\mathrm{f}_{0}$ & $81,5 \%$ & $70,2 \%$ & $47,5 \%$ & $84,2 \%$ & $69,0 \%$ \\
\hline & $\mathrm{ff}_{1 \text { avg }}$ & 0,34 & 0,48 & 0,81 & 0,33 & 0,51 \\
\hline & $\mathrm{ff}_{2}$ avg & 0,04 & 0,07 & 0,11 & 0,05 & 0,07 \\
\hline & $\mathrm{ff}_{3}$ avg & 0,93 & 0,59 & 0,63 & 0,50 & 0,54 \\
\hline & $\mathrm{ff}_{4}$ avg & 1,96 & 2,03 & 2,33 & 2,25 & 2,24 \\
\hline \multirow[t]{5}{*}{2007} & $\mathrm{f}_{0}$ & $37,6 \%$ & $43,3 \%$ & $58,5 \%$ & $38,0 \%$ & $39,4 \%$ \\
\hline & $\mathrm{ff}_{1}$ avg & 0,97 & 0,83 & 0,72 & 0,90 & 0,84 \\
\hline & $\mathrm{ff}_{2}$ avg & 0,38 & 0,20 & 0,18 & 0,19 & 0,25 \\
\hline & $\mathrm{ff}_{3}$ avg & 2,12 & 1,52 & 1,51 & 1,70 & 1,45 \\
\hline & $\mathrm{ff}_{4}$ avg & 3,87 & 2,45 & 2,72 & 3,17 & 1,69 \\
\hline \multirow[t]{5}{*}{2008} & $f_{0}$ & $49,8 \%$ & $52,1 \%$ & $70,4 \%$ & $67,3 \%$ & $55,0 \%$ \\
\hline & $\mathrm{ff}_{1 \text { avg }}$ & 0,24 & 0,22 & 0,13 & 0,14 & 0,27 \\
\hline & $\mathrm{ff}_{2}$ avg & 0,13 & 0,07 & 0,08 & 0,05 & 0,09 \\
\hline & $\mathrm{ff}_{3}$ avg & 1,33 & 1,27 & 0,88 & 0,70 & 1,35 \\
\hline & $\mathrm{ff}_{4}$ avg & 3,46 & 3,27 & 3,19 & 2,87 & 2,64 \\
\hline \multirow[t]{5}{*}{2009} & $\mathrm{f}_{0}$ & $71,1 \%$ & $38,5 \%$ & $48,8 \%$ & $52,6 \%$ & $42,8 \%$ \\
\hline & $\mathrm{ff}_{1 \text { avg }}$ & 0,41 & 0,93 & 0,88 & 0,76 & 0,83 \\
\hline & $\mathrm{ff}_{2}$ avg & 0,04 & 0,11 & 0,10 & 0,07 & 0,09 \\
\hline & $\mathrm{ff}_{3}$ avg & 1,53 & 1,92 & 1,74 & 1,59 & 1,78 \\
\hline & $\mathrm{ff}_{4}$ avg & 3,04 & 2,38 & 2,98 & 1,80 & 2,71 \\
\hline \multirow[t]{5}{*}{2010} & $\mathrm{f}_{0}$ & $56,5 \%$ & $48,8 \%$ & $47,3 \%$ & $45,5 \%$ & $46,3 \%$ \\
\hline & $\mathrm{ff}_{1}$ avg & 0,29 & 0,43 & 0,41 & 0,46 & 0,41 \\
\hline & $\mathrm{ff}_{2}$ avg & 0,05 & 0,06 & 0,06 & 0,05 & 0,05 \\
\hline & $\mathrm{ff}_{3}$ avg & 0,74 & 0,91 & 0,86 & 1,11 & 0,81 \\
\hline & $\mathrm{ff}_{4}$ avg & 2,54 & 0,82 & 1,15 & 1,75 & 0,68 \\
\hline \multirow[t]{5}{*}{2011} & $\mathrm{f}_{0}$ & $47,4 \%$ & $70,0 \%$ & $71,2 \%$ & $50,8 \%$ & $78,7 \%$ \\
\hline & $\mathrm{ff}_{1 \text { avg }}$ & 0,12 & 0,23 & 0,23 & 0,36 & 0,18 \\
\hline & $\mathrm{ff}_{2}$ avg & 0,04 & 0,05 & 0,08 & 0,08 & 0,04 \\
\hline & $\mathrm{ff}_{3}$ avg & 1,19 & 1,19 & 1,41 & 1,46 & 1,19 \\
\hline & $\mathrm{ff}_{4}$ avg & 3,89 & 3,33 & 2,87 & 2,91 & 3,33 \\
\hline 2012 & $f_{0}$ & $13,6 \%$ & $30,4 \%$ & $24,4 \%$ & $30,2 \%$ & $30,4 \%$ \\
\hline & $\mathrm{ff}_{1}$ avg & 1,09 & 0,77 & 0,87 & 0,78 & 0,81 \\
\hline & $\mathrm{ff}_{2}$ avg & 0,41 & 0,22 & 0,26 & 0,23 & 0,22 \\
\hline & $\mathrm{ff}_{3}$ avg & 1,72 & 1,34 & 1,16 & 1,35 & 1,29 \\
\hline & $\mathrm{ff}_{4}$ avg & 2,76 & 3,22 & 3,18 & 3,13 & 3,44 \\
\hline
\end{tabular}

(continued on next page) 
Table 2 (continued)

\begin{tabular}{lllllll}
\hline Year & Variable* & Negotin & Zrenjanin & $\begin{array}{l}\text { Sremska } \\
\text { Mitrovica }\end{array}$ & $\begin{array}{l}\text { Banatski } \\
\text { Karlovac }- \\
\text { Alibunar } \\
89\end{array}$ & $\begin{array}{l}\text { Kikinda - } \\
\text { Coka }\end{array}$ \\
& $\begin{array}{l}\text { Altitude } \\
\text { (in m) }\end{array}$ & 42 & 80 & 81 & 96 & \\
\hline 2013 & & & & & & \\
& $\mathrm{f}_{0}$ & $14,8 \%$ & $36,7 \%$ & $26,7 \%$ & $51,0 \%$ & $32,2 \%$ \\
& $\mathrm{ff}_{1 \text { avg }}$ & 1,01 & 0,82 & 1,06 & 0,58 & 0,83 \\
& $\mathrm{ff}_{2 \text { avg }}$ & 0,06 & 0,07 & 0,12 & 0,06 & 0,06 \\
& $\mathrm{ff}_{3 \text { avg }}$ & 1,18 & 0,96 & 1,13 & 1,10 & 0,93 \\
& $\mathrm{ff}_{4}$ avg & 2,88 & 2,16 & 1,74 & 2,20 & 2,33 \\
\hline
\end{tabular}

$\mathrm{f}_{0}$ - planting day.

$\mathrm{ff}_{1}-\mathrm{ff}_{4}$ - subperiods.

One of the prerequisites for creating the panel was the definition of four sub-periods (several phenophases) within the vegetation season of winter wheat. The division is based on the scientific and practical experience of persons oriented to the field of crop farming (information collected through in-depth interviews with the scientific-teaching staff of the Faculty of Agriculture and research staff of the scientific institute) and generally available literary sources. Consequently, the defined subperiods were derived from an adequate grouping of all morphological stages of growth and 12 stages of organogenesis of winter wheat, which characterizes the agro-ecological conditions of Serbia (Đorđević et al., 1965; Jevtić, 1977; Glamočlija, 2012; IAE, 2016):

1) the first defined sub-period, lasting from October 15th to November 15 th, covered the phenophases initiated by the planting process, i.e., the period from germination to the emergence of wheat, which is in a time overlap with the first stage of organogenesis (characterized by the undifferentiated vegetative cone);

2) the second sub-period covers the period from November 15th to April 1st and includes the morphological phases of tillering and seedling. These include the second stage (differentiation of the lower part of the vegetative cone to the stem and leaf buds, as well as the differentiation of the tillering node), the third stage (differentiation of the upper part of the vegetative cone, i.e. the differentiation of the ear fusiform spike) and the fourth stage (differentiation of spikelets, i.e., budding of spikelet glume) of winter wheat organogenesis;

3) the third defined sub-period covers the period from April 1st to May 15 th and involves jointing and heading phases. These are the fifth stage (differentiation of flower buds, i.e., flower sheath), the sixth stage (differentiation of reproductive parts), the seventh stage (characterized by gametogenesis and dimensional enlargement of the differentiated parts) and the eighth stage (overlaps with the phenolic phase of heading) of organogenesis; and

4) the fourth determined sub-period lasts from May 15th to July 1st and implies phenological phases of flowering and pollination, fertilization and grain forming, and the stage of its ripeness until reaching full ripeness. These are the ninth stage (it coincides with the morphological phase of flowering and pollination), the tenth stage (it coincides with the morphological stage of fertilization and grain formation), the eleventh stage (the stage of ripeness as a transition between milk and wax ripeness) and the twelfth stage (the stage of ripeness as a transition between wax and full ripeness) of wheat organogenesis.

Econometric model in this study follows the work of Zubović et al. (2017), who proposes the application of a spatial panel model to assess the impact of weather factors on maize yields in Serbia. The methodology is primarily designed to analyze the impact of the presence of water in the soil, as the main determinants of evapotranspiration, on wheat yield using the regression model with composite error, shown by the following equation (subscript $i$ refers to the municipality, while $t$ refers to the year):

$$
Y_{i, t}=\alpha+X_{i, t} \gamma+Z_{i, t} \delta+\eta_{i}+\varepsilon_{i, t}
$$

Variables in the equation have the following meaning:

$Y_{i, t}$ - average wheat yield expressed in kilograms per hectare; ${ }^{1}$

$X_{i, t}$ - measurement of water scarcity in soil by subperiods (phenophases) for wheat;

$Z_{i, t}$ - control variables;

$\eta_{i}$ - individual effects of the municipality; and

$\varepsilon_{i, t}$ - random error, $\varepsilon_{i, t} \tilde{N}\left(0, \sigma^{2}\right)$

Measurements of water scarcity ${ }^{2} X_{i, t}$ are defined for each phenophase $m(m=1, \ldots, 4), X_{i, t}=\left\{f \bar{f}_{i, t}^{m}\right\}$, where $f \bar{f}_{i, t}^{m}$ represents the average daily deficiency of water in the phenophase $m$. If $l^{m}$ marks the duration of the phenophase $m$ in days, the calculation of the average daily water scarcity $f \bar{f}_{i, t}^{m}$ in the phenophase $m$, can be mathematically explained in the next three steps:

1) for each day in the given phenophase, the difference between the daily potential evapotranspiration $e t_{i, t}^{m, p}$ and actual daily evapotranspiration $e t_{i, t}^{m, r}$ is calculated

$\Delta e t_{i, t}^{m}=e t_{i, t}^{m, p}-e t_{i, t}^{m, r}$

2) for each phenophase, total water deficit $\mathrm{ff}_{\mathrm{i}, \mathrm{t} ; \mathrm{j}}^{\mathrm{m}}$ is calculated by summing up the difference between daily potential and actual evapotranspiration

$f f_{i, t ; j}^{m}=\sum_{j}^{l^{m}} \Delta e t_{i, t ; j}^{m}$

3) the total water scarcity is averaged by its length expressed in days $l^{m}$

$f \bar{f}_{i, t}^{m}=f f_{i, t}^{m} / l^{m}$

Potential and actual evapotranspiration are calculated using the Hargreaves formula. ${ }^{3}$

Saturation of soil moisture on the wheat planting day ( $15^{\text {th }}$ October) $f f_{i, t}^{0}$, the share of harvest areas under wheat in the total arable area $\mathrm{P}_{\mathrm{i}, \mathrm{t}}$, as well as the annual change in harvest areas under wheat $\Delta \mathrm{P}_{\mathrm{i}, \mathrm{t}}$, expressed in percentage points, were used as control variables. Soil moisture saturation $\mathrm{ff}_{\mathrm{i}, \mathrm{t}}^{0}$ is calculated as the moisture ratio on the day of planting $\omega_{\mathrm{i}, \mathrm{t}}^{0}$ and field water capacity $\omega_{\mathrm{i}, \mathrm{t}}^{*}$.

$f f_{i, t}^{0}=\omega_{i, t}^{0} / \omega_{i, t}^{*}$

The purpose of using this variable as a control variable is based on the expectation that a higher water concentration in the soil on the day of planting (if not excessive) can stimulate germination and sprouting of wheat. The ratio between the yield of wheat and share of land $\mathrm{P}_{\mathrm{i}, \mathrm{t}}$

\footnotetext{
${ }^{1}$ The impact of higher yields achieved by irrigation on the value of average yields is eliminated by the fact that the share of irrigated areas in the total agricultural land used is below 3\% (Pavlović et al., 2017), with only about 1.5\% of these areas in the intensive irrigation system (Kljajić et al., 2013).

${ }^{2}$ Reference evapotranspiration is an essential element in determining plant's needs for water (satisfying the level of transpiration and evaporation of water from the soil) in certain agro-ecological conditions, designing norms and optimal irrigation regimes, dimensioning irrigation systems, etc. (Bezdan et al., 2017). Therefore, it can be used to determine the impact of weather factors on the level of fulfillment of crop's water demand requirements, as well as the deficient quantities of water that would be compensated from precipitation, irrigation or water reserve in the soil. In other words, based on the calculated value for reference evapotranspiration corrected by the appropriate coefficient for specific crop, an estimate can be performed for the daily water scarcity to be added to the crop through irrigation (Trajković, 2009).

${ }^{3}$ On a world scale, in terms of precision, the use of methods for determining the reference evapotranspiration by Penman-Monteith (FAO56-PM) model is suggested. At the level of Serbia, a simplified Hargreaves model is used (one of the globally most commonly used methods), where daily calculations are based on maximum, minimum and average temperature, extraterrestrial radiation of the sun and the length of the day at a certain location (RHSS, 2016).
} 
theoretically it can be positive (if the land is suitable for cultivation of wheat, a greater share of areas and higher yields will be achieved at the same time), but also negative (if wheat is cultivated on the arable land margins, which are characterized by lower fertility and thus reduced average yield). The above mentioned suggests an inverse ratio between changes in the share of surfaces $\Delta \mathrm{P}_{\mathrm{i}, \mathrm{t}}$ and yield of wheat, as a consequence of wheat not being planted on arable land where lower yields are realized.

Municipality's altitude $\mathrm{Alt}_{\mathrm{i}}$ is a time-invariant variable that has an impact on wheat yield. Since the explicit impact of altitude on the yields is an issue of particular importance for research, the categorical variable Alt $_{\mathrm{i}}$ is defined, based on the grouping of municipalities in the following three categories according to their altitude:

Alt $_{i}=\left\{\begin{array}{l}1 ; \text { Alt }_{i}<100 \\ 2 ; 101 \leq \text { Alt }_{i}<200 \\ 3 ; \text { Alt }_{i} \geq 201\end{array}\right\}$

This grouping was carried out according to the same matrix used for the stratification of municipalities given the criteria of altitude for creating a sample. Using the variable Alt $_{\mathrm{i}}$ a pooled regression model (pooled - because it does not take into account the individual specificities of the observation units when analyzing the impact on the dependent variable) is evaluated as a benchmark for comparison with the model with a composite error. Subsequently, three particular models with the composite error were assessed for each sub-sample of municipalities by categories of altitude, to analyze potential differences in the intensity and significance of the impact of explanatory variables on wheat yield.

The methodological limitations of the conducted research include conceptual limitations (coming from the model simplification of reality) and estimation limitations (arising from the general limitation of the statistical methods used for the analysis). The main conceptual limitations of the conducted research were:

- Only ordinary mercantile winter wheat was considered;

- Defined phenophases are of general significance for all observed municipalities, regardless of potential differences in the locality. Also, the beginning and end dates of individual phenophases in specific years may vary depending on weather conditions, which is not taken into account due to the lack of specific data from previous years;

- The lack of data has caused the neglect of the influence of mineral fertilizers and pesticides (by type and quantity) on the realized yield of wheat.

The basic estimation limitations in evaluating the created model are related to the limited possibilities of statistical analysis methods to eliminate the following problems often present in the analysis of actual data:

- The presence of high collinearity i.e., a pronounced correlation between independent variables that prevent precise delineation of the influence of individual independent variables on the dependent variable;

- The presence of unobserved heterogeneity due to influential factors that are not explicitly covered by the model;

- Measurement errors in variables, as a direct consequence of the conceptual limitations, stated above.

Each of these limitations is a potential source of the unreliability of regression assessment, so we address them later in the analysis.

\section{Results}

Data on saturation of soil moisture on the planting day $\left(f_{0}\right)$, as well
Table 3

Saturation of soil moisture on the wheat planting day (in \%) and average daily water deficiency (in $\mathrm{mm}$ ) by sub-periods in municipalities. 100-200 m

Source: Jelonik, 2017.

\begin{tabular}{|c|c|c|c|c|c|}
\hline Year & $\begin{array}{l}\text { Variable* } \\
\text { Altitude (in m) }\end{array}$ & $\begin{array}{l}\text { Palić -Subotica } \\
102\end{array}$ & $\begin{array}{l}\text { Loznica } \\
121\end{array}$ & $\begin{array}{l}\text { Ćuprija } \\
123\end{array}$ & $\begin{array}{l}\text { Zaječar } \\
144\end{array}$ \\
\hline \multirow[t]{5}{*}{2000} & $\mathrm{f}_{0}$ & $58,6 \%$ & $49,2 \%$ & $43,4 \%$ & $18,7 \%$ \\
\hline & $\mathrm{ff}_{1 \text { avg }}$ & 0,45 & 0,56 & 0,63 & 0,71 \\
\hline & $\mathrm{ff}_{2 \text { avg }}$ & 0,06 & 0,04 & 0,10 & 0,19 \\
\hline & $\mathrm{ff}_{3 \text { avg }}$ & 1,15 & 1,33 & 1,24 & 2,09 \\
\hline & $\mathrm{ff}_{4}$ avg & 4,12 & 3,21 & 4,29 & 5,13 \\
\hline \multirow{5}{*}{2001} & $\mathrm{f}_{0}$ & $12,0 \%$ & $54,5 \%$ & $37,4 \%$ & $36,7 \%$ \\
\hline & $\mathrm{ff}_{1 \text { avg }}$ & 1,28 & 0,83 & 1,05 & 0,97 \\
\hline & $\mathrm{ff}_{2}$ avg & 0,39 & 0,16 & 0,48 & 0,47 \\
\hline & $\mathrm{ff}_{3}$ avg & 0,43 & 0,44 & 0,64 & 0,88 \\
\hline & $\mathrm{ff}_{4}$ avg & 1,07 & 1,31 & 1,84 & 1,98 \\
\hline \multirow[t]{5}{*}{2002} & $\mathrm{f}_{0}$ & $66,6 \%$ & $74,1 \%$ & $73,5 \%$ & $43,3 \%$ \\
\hline & $\mathrm{ff}_{1 \text { avg }}$ & 0,43 & 0,43 & 0,53 & 0,89 \\
\hline & $\mathrm{ff}_{2}$ avg & 0,17 & 0,11 & 0,19 & 0,63 \\
\hline & $\mathrm{ff}_{3 \text { avg }}$ & 1,68 & 0,51 & 0,97 & 2,07 \\
\hline & $\mathrm{ff}_{4}$ avg & 3,03 & 1,65 & 2,34 & 3,97 \\
\hline \multirow[t]{5}{*}{2003} & $\mathrm{f}_{0}$ & $44,0 \%$ & $100,0 \%$ & $95,8 \%$ & $100,0 \%$ \\
\hline & $\mathrm{ff}_{1 \text { avg }}$ & 0,63 & 0,03 & 0,09 & 0,09 \\
\hline & $\mathrm{ff}_{2}$ avg & 0,18 & 0,10 & 0,11 & 0,11 \\
\hline & $\mathrm{ff}_{3 \text { avg }}$ & 2,04 & 2,12 & 1,89 & 1,20 \\
\hline & $\mathrm{ff}_{4}$ avg & 4,20 & 3,80 & 3,92 & 3,13 \\
\hline \multirow[t]{5}{*}{2004} & $f_{0}$ & $68,3 \%$ & $72,4 \%$ & $54,3 \%$ & $52,5 \%$ \\
\hline & $\mathrm{ff}_{1 \text { avg }}$ & 0,14 & 0,12 & 0,19 & 0,10 \\
\hline & $\mathrm{ff}_{2}$ avg & 0,04 & 0,06 & 0,05 & 0,06 \\
\hline & $\mathrm{ff}_{3 \text { avg }}$ & 0,48 & 0,42 & 1,17 & 0,91 \\
\hline & $\mathrm{ff}_{4}$ avg & 1,86 & 1,10 & 2,27 & 2,77 \\
\hline \multirow[t]{5}{*}{2005} & $f_{0}$ & $63,4 \%$ & $83,2 \%$ & $60,9 \%$ & $46,8 \%$ \\
\hline & $\mathrm{ff}_{1 \text { avg }}$ & 0,33 & 0,18 & 0,58 & 0,55 \\
\hline & $\mathrm{ff}_{2}$ avg & 0,03 & 0,03 & 0,04 & 0,06 \\
\hline & $\mathrm{ff}_{3}$ avg & 0,61 & 0,48 & 0,53 & 0,97 \\
\hline & $\mathrm{ff}_{4}$ avg & 1,21 & 0,76 & 1,85 & 2,36 \\
\hline \multirow[t]{5}{*}{2006} & $\mathrm{f}_{0}$ & $77,0 \%$ & $85,3 \%$ & $87,0 \%$ & $84,6 \%$ \\
\hline & $\mathrm{ff}_{1 \text { avg }}$ & 0,38 & 0,29 & 0,31 & 0,34 \\
\hline & $\mathrm{ff}_{2}$ avg & 0,05 & 0,04 & 0,03 & 0,05 \\
\hline & $\mathrm{ff}_{3 \text { avg }}$ & 0,40 & 0,36 & 0,64 & 1,15 \\
\hline & $\mathrm{ff}_{4}$ avg & 1,01 & 1,55 & 2,82 & 2,93 \\
\hline \multirow[t]{5}{*}{2007} & $\mathrm{f}_{0}$ & $40,1 \%$ & $84,8 \%$ & $38,2 \%$ & $52,5 \%$ \\
\hline & $\mathrm{ff}_{1 \text { avg }}$ & 0,79 & 0,37 & 0,93 & 0,83 \\
\hline & $\mathrm{ff}_{2 \text { avg }}$ & 0,29 & 0,09 & 0,15 & 0,46 \\
\hline & $\mathrm{ff}_{3}$ avg & 1,49 & 1,50 & 1,96 & 2,38 \\
\hline & $\mathrm{ff}_{4}$ avg & 1,94 & 2,70 & 2,68 & 3,55 \\
\hline \multirow[t]{5}{*}{2008} & $\mathrm{f}_{0}$ & $37,0 \%$ & $95,4 \%$ & $64,6 \%$ & $83,0 \%$ \\
\hline & $\mathrm{ff}_{1 \text { avg }}$ & 0,37 & 0,03 & 0,21 & 0,10 \\
\hline & $\mathrm{ff}_{2 \text { avg }}$ & 0,06 & 0,03 & 0,08 & 0,13 \\
\hline & $\mathrm{ff}_{3 \text { avg }}$ & 0,82 & 0,67 & 0,90 & 1,15 \\
\hline & $\mathrm{ff}_{4}$ avg & 1,52 & 1,66 & 3,89 & 3,93 \\
\hline \multirow[t]{5}{*}{2009} & $\mathrm{f}_{0}$ & $50,9 \%$ & $66,3 \%$ & $52,9 \%$ & $62,1 \%$ \\
\hline & $\mathrm{ff}_{1 \text { avg }}$ & 0,69 & 0,66 & 0,82 & 0,58 \\
\hline & $\mathrm{ff}_{2 \text { avg }}$ & 0,09 & 0,06 & 0,08 & 0,07 \\
\hline & $\mathrm{ff}_{3 \text { avg }}$ & 1,84 & 1,27 & 1,52 & 1,40 \\
\hline & $\mathrm{ff}_{4}$ avg & 2,55 & 1,82 & 2,44 & 3,39 \\
\hline \multirow[t]{5}{*}{2010} & $\mathrm{f}_{0}$ & $60,3 \%$ & $75,9 \%$ & $54,5 \%$ & $68,6 \%$ \\
\hline & $\mathrm{ff}_{1 \text { avg }}$ & 0,32 & 0,10 & 0,32 & 0,19 \\
\hline & $\mathrm{ff}_{2}$ avg & 0,04 & 0,03 & 0,07 & 0,06 \\
\hline & $\mathrm{ff}_{3 \text { avg }}$ & 0,77 & 0,61 & 0,96 & 0,76 \\
\hline & $\mathrm{ff}_{4}$ avg & 1,03 & 0,69 & 1,60 & 2,26 \\
\hline 2011 & $\mathrm{f}_{0}$ & $83,2 \%$ & $87,4 \%$ & $37,1 \%$ & $37,2 \%$ \\
\hline & $\mathrm{ff}_{1 \text { avg }}$ & 0,09 & 0,08 & 0,56 & 0,51 \\
\hline & $\mathrm{ff}_{2}$ avg & 0,03 & 0,07 & 0,10 & 0,08 \\
\hline & $\mathrm{ff}_{3 \text { avg }}$ & 1,15 & 0,92 & 1,19 & 1,30 \\
\hline & $\mathrm{ff}_{4}$ avg & 2,58 & 2,54 & 3,65 & 3,62 \\
\hline 2012 & $\mathrm{f}_{0}$ & $33,8 \%$ & $31,3 \%$ & $30,9 \%$ & $23,8 \%$ \\
\hline & $\mathrm{ff}_{1 \text { avg }}$ & 0,72 & 0,82 & 0,93 & 0,95 \\
\hline & $\mathrm{ff}_{2}$ avg & 0,19 & 0,20 & 0,27 & 0,41 \\
\hline & $\mathrm{ff}_{3 \text { avg }}$ & 1,47 & 0,74 & 0,91 & 1,85 \\
\hline & $\mathrm{ff}_{4}$ avg & 3,23 & 2,20 & 3,12 & 2,66 \\
\hline 2013 & $\mathrm{f}_{0}$ & $40,3 \%$ & $42,0 \%$ & $24,7 \%$ & $12,1 \%$ \\
\hline & $\mathrm{ff}_{1 \text { avg }}$ & 0,68 & 0,90 & 1,04 & 1,12 \\
\hline & $\mathrm{ff}_{2}$ avg & 0,04 & 0,05 & 0,08 & 0,09 \\
\hline & $\mathrm{ff}_{3}$ avg & 0,91 & 0,86 & 1,26 & 1,26 \\
\hline & $\mathrm{ff}_{4}$ avg & 2,06 & 1,27 & 2,56 & 3,39 \\
\hline
\end{tabular}

$\mathrm{f}_{0}$ - planting day.

$\mathrm{ff}_{1}-\mathrm{ff}_{4}$ - subperiods. 
Table 4

Saturation of soil moisture on the wheat planting day (in \%) and average daily water deficiency (in $\mathrm{mm}$ ) by sub-periods in municipalities over the $200 \mathrm{~m}$. Source: Jelonik, 2017.

\begin{tabular}{|c|c|c|c|c|c|c|}
\hline Year & $\begin{array}{l}\text { Variable* }^{*} \\
\text { Altitude (in m) }\end{array}$ & $\begin{array}{l}\text { Kragujevac } \\
200\end{array}$ & $\begin{array}{l}\text { Kraljevo } \\
215\end{array}$ & $\begin{array}{l}\text { Leskovac } \\
230\end{array}$ & $\begin{array}{l}\text { Požega } \\
310\end{array}$ & $\begin{array}{l}\text { Vranje } \\
432\end{array}$ \\
\hline \multirow[t]{5}{*}{2000} & $f_{0}$ & $46,5 \%$ & $53,5 \%$ & $22,4 \%$ & $59,4 \%$ & $17,1 \%$ \\
\hline & $\mathrm{ff}_{1 \text { avg }}$ & 0,60 & 0,44 & 0,86 & 0,36 & 0,88 \\
\hline & $\mathrm{ff}_{2}$ avg & 0,11 & 0,05 & 0,11 & 0,05 & 0,11 \\
\hline & $\mathrm{ff}_{3}$ avg & 1,88 & 1,53 & 1,44 & 1,38 & 1,32 \\
\hline & $\mathrm{ff}_{4}$ avg & 4,40 & 3,88 & 4,01 & 3,46 & 4,44 \\
\hline \multirow[t]{5}{*}{2001} & $f_{0}$ & $49,5 \%$ & $52,9 \%$ & $33,9 \%$ & $51,5 \%$ & $19,9 \%$ \\
\hline & $\mathrm{ff}_{1 \text { avg }}$ & 0,89 & 0,66 & 1,14 & 0,76 & 1,23 \\
\hline & $\mathrm{ff}_{2}$ avg & 0,44 & 0,24 & 0,44 & 0,18 & 0,59 \\
\hline & $\mathrm{ff}_{3}$ avg & 0,56 & 0,42 & 0,59 & 0,52 & 0,81 \\
\hline & $\mathrm{ff}_{4}$ avg & 1,96 & 1,79 & 2,59 & 1,92 & 2,72 \\
\hline \multirow[t]{5}{*}{2002} & $\mathrm{f}_{0}$ & $75,8 \%$ & $75,8 \%$ & $38,9 \%$ & $78,0 \%$ & $31,3 \%$ \\
\hline & $\mathrm{ff}_{1 \text { avg }}$ & 0,45 & 0,46 & 1,11 & 0,38 & 1,19 \\
\hline & $\mathrm{ff}_{2}$ avg & 0,17 & 0,14 & 0,30 & 0,15 & 0,39 \\
\hline & $\mathrm{ff}_{3 \text { avg }}$ & 1,13 & 0,46 & 0,96 & 0,55 & 1,06 \\
\hline & $\mathrm{ff}_{4}$ avg & 3,00 & 2,09 & 2,70 & 2,69 & 2,24 \\
\hline \multirow[t]{5}{*}{2003} & $f_{0}$ & $100,0 \%$ & $100,0 \%$ & $99,0 \%$ & $100,0 \%$ & $100,0 \%$ \\
\hline & $\mathrm{ff}_{1 \text { avg }}$ & 0,06 & 0,11 & 0,13 & 0,11 & 0,10 \\
\hline & $\mathrm{ff}_{2}$ avg & 0,11 & 0,10 & 0,11 & 0,11 & 0,12 \\
\hline & $\mathrm{ff}_{3}$ avg & 1,88 & 1,95 & 1,58 & 2,14 & 2,09 \\
\hline & $\mathrm{ff}_{4}$ avg & 3,36 & 2,62 & 3,63 & 2,42 & 3,64 \\
\hline \multirow[t]{5}{*}{2004} & $\mathrm{f}_{0}$ & $33,1 \%$ & $43,9 \%$ & $56,2 \%$ & $26,8 \%$ & $54,8 \%$ \\
\hline & $\mathrm{ff}_{1 \text { avg }}$ & 0,46 & 0,29 & 0,17 & 0,51 & 0,17 \\
\hline & $\mathrm{ff}_{2}$ avg & 0,11 & 0,07 & 0,05 & 0,12 & 0,05 \\
\hline & $\mathrm{ff}_{3}$ avg & 0,99 & 0,91 & 0,98 & 0,86 & 0,75 \\
\hline & $\mathrm{ff}_{4}$ avg & 2,41 & 1,54 & 2,58 & 1,71 & 2,24 \\
\hline \multirow[t]{5}{*}{2005} & $f_{0}$ & $63,9 \%$ & $67,7 \%$ & $68,3 \%$ & $60,1 \%$ & $71,5 \%$ \\
\hline & $\mathrm{ff}_{1 \text { avg }}$ & 0,54 & 0,49 & 0,54 & 0,58 & 0,50 \\
\hline & $\mathrm{ff}_{2}$ avg & 0,05 & 0,04 & 0,04 & 0,04 & 0,06 \\
\hline & $\mathrm{ff}_{3}$ avg & 0,43 & 0,65 & 0,53 & 0,93 & 1,37 \\
\hline & $\mathrm{ff}_{4}$ avg & 1,91 & 1,20 & 1,58 & 1,80 & 2,81 \\
\hline \multirow[t]{5}{*}{2006} & $\mathrm{f}_{0}$ & $85,6 \%$ & $86,6 \%$ & $67,6 \%$ & $77,3 \%$ & $73,8 \%$ \\
\hline & $\mathrm{ff}_{1 \text { avg }}$ & 0,35 & 0,28 & 0,60 & 0,34 & 0,50 \\
\hline & $\mathrm{ff}_{2}$ avg & 0,03 & 0,03 & 0,07 & 0,02 & 0,05 \\
\hline & $\mathrm{ff}_{3}$ avg & 0,55 & 0,46 & 0,51 & 0,45 & 0,65 \\
\hline & $\mathrm{ff}_{4}$ avg & 2,40 & 1,89 & 2,11 & 1,49 & 1,86 \\
\hline \multirow[t]{5}{*}{2007} & $\mathrm{f}_{0}$ & $65,0 \%$ & $65,7 \%$ & $71,7 \%$ & $68,7 \%$ & $54,3 \%$ \\
\hline & $\mathrm{ff}_{1}$ avg & 0,64 & 0,58 & 0,55 & 0,53 & 0,78 \\
\hline & $\mathrm{ff}_{2}$ avg & 0,16 & 0,11 & 0,15 & 0,11 & 0,21 \\
\hline & $\mathrm{ff}_{3}$ avg & 1,63 & 1,47 & 1,67 & 1,48 & 1,60 \\
\hline & $\mathrm{ff}_{4}$ avg & 2,88 & 2,53 & 3,03 & 2,41 & 2,90 \\
\hline \multirow[t]{5}{*}{2008} & $\mathrm{f}_{0}$ & $54,8 \%$ & $73,8 \%$ & $53,8 \%$ & $90,2 \%$ & $50,1 \%$ \\
\hline & $\mathrm{ff}_{1 \text { avg }}$ & 0,36 & 0,12 & 0,30 & 0,05 & 0,41 \\
\hline & $\mathrm{ff}_{2}$ avg & 0,07 & 0,05 & 0,14 & 0,08 & 0,13 \\
\hline & $\mathrm{ff}_{3}$ avg & 1,04 & 0,51 & 0,96 & 0,81 & 0,88 \\
\hline & $\mathrm{ff}_{4}$ avg & 3,74 & 2,70 & 3,56 & 2,42 & 3,23 \\
\hline \multirow[t]{5}{*}{2009} & $\mathrm{f}_{0}$ & $50,6 \%$ & $76,5 \%$ & $55,2 \%$ & $57,5 \%$ & $76,5 \%$ \\
\hline & $\mathrm{ff}_{1}$ avg & 0,82 & 0,43 & 0,98 & 0,67 & 0,59 \\
\hline & $\mathrm{ff}_{2}$ avg & 0,13 & 0,05 & 0,08 & 0,06 & 0,07 \\
\hline & $\mathrm{ff}_{3}$ avg & 1,34 & 1,34 & 1,33 & 1,35 & 1,07 \\
\hline & $\mathrm{ff}_{4}$ avg & 2,32 & 2,14 & 2,66 & 2,17 & 2,35 \\
\hline 2010 & $\mathrm{f}_{0}$ & $69,9 \%$ & $79,9 \%$ & $54,6 \%$ & $70,7 \%$ & $59,3 \%$ \\
\hline & $\mathrm{ff}_{1 \text { avg }}$ & 0,19 & 0,06 & 0,34 & 0,20 & 0,34 \\
\hline & $\mathrm{ff}_{2}$ avg & 0,05 & 0,05 & 0,05 & 0,05 & 0,06 \\
\hline & $\mathrm{ff}_{3}$ avg & 0,66 & 0,68 & 0,80 & 1,14 & 0,70 \\
\hline & $\mathrm{ff}_{4}$ avg & 1,13 & 1,06 & 2,23 & 1,60 & 2,10 \\
\hline 2011 & $\mathrm{f}_{0}$ & $48,1 \%$ & $41,7 \%$ & $37,2 \%$ & $48,7 \%$ & $51,4 \%$ \\
\hline & $\mathrm{ff}_{1}$ avg & 0,38 & 0,37 & 0,73 & 0,43 & 0,31 \\
\hline & $\mathrm{ff}_{2}$ avg & 0,09 & 0,07 & 0,11 & 0,09 & 0,10 \\
\hline & $\mathrm{ff}_{3}$ avg & 1,17 & 0,73 & 1,32 & 1,04 & 1,50 \\
\hline & $\mathrm{ff}_{4}$ avg & 3,14 & 2,14 & 3,35 & 2,69 & 3,69 \\
\hline 2012 & $f_{0}$ & $39,7 \%$ & $34,4 \%$ & $47,8 \%$ & $41,6 \%$ & $49,9 \%$ \\
\hline & $\mathrm{ff}_{1 \text { avg }}$ & 0,83 & 0,90 & 0,87 & 0,73 & 0,84 \\
\hline & $\mathrm{ff}_{2}$ avg & 0,25 & 0,22 & 0,22 & 0,20 & 0,22 \\
\hline & $\mathrm{ff}_{3}$ avg & 1,31 & 1,07 & 1,53 & 1,33 & 1,33 \\
\hline & $\mathrm{ff}_{4}$ avg & 2,72 & 2,82 & 2,80 & 2,59 & 2,68 \\
\hline 2013 & $\mathrm{f}_{0}$ & $20,7 \%$ & $21,5 \%$ & $13,0 \%$ & $21,3 \%$ & $20,9 \%$ \\
\hline & $\mathrm{ff}_{1 \text { avg }}$ & 1,10 & 1,15 & 1,41 & 1,22 & 1,24 \\
\hline & $\mathrm{ff}_{2}$ avg & 0,10 & 0,10 & 0,14 & 0,08 & 0,13 \\
\hline & $\mathrm{ff}_{3}$ avg & 1,18 & 1,07 & 1,22 & 1,20 & 1,08 \\
\hline & $\mathrm{ff}_{4}$ avg & 2,10 & 1,43 & 2,78 & 1,74 & 2,47 \\
\hline
\end{tabular}

$\mathrm{f}_{0}$ - planting day.

$\mathrm{ff}_{1}-\mathrm{ff}_{4}$ - subperiods. as the average daily water scarcity in the four previously determined sub-periods $\left(\mathrm{ff}_{1}-\mathrm{ff}_{4}\right)$ in the wheat vegetation season for selected municipalities for the altitudes $0-100 \mathrm{~m}$ is given in Table 2, for $100-200 \mathrm{~m}$ in Table 3, and above $200 \mathrm{~m}$ in Table 4 . Wheat annual yields and changes in the size of harvested areas is given in Table 5 for the altitudes 0-100 m, in Table 6 for $100-200 \mathrm{~m}$, and in Table 7 for the altitudes $200 \mathrm{~m}$ and above. Observed municipalities are grouped according to altitude delimitation, as explained in the previous section.

Table 8 shows a correlation matrix of the explanatory variables. Estimated correlation coefficients do not indicate the problem of too high multicollinearity in the model. In addition to simple correlation analysis, we consulted more formal collinearity diagnostics in the form of Variance Inflation Factor (VIF) analysis. Collinearity tolerance indicator shows portion of variations in the particular variable that cannot be explained by variations in other variables on the explanatory side of the regression equation. The usual interpretation of the collinearity diagnostic is that values of the VIF (VIF is inverse of collinearity tolerance) higher than 10 indicates a problem with collinearity (Craney and Surles, 2002). In our case, the values of the VIF are quite low, so we can conclude that the problem of excessive collinearity doesn't affect our explanatory variables. Results of collinearity diagnostic are presented in Table 9.

The issue of unobserved heterogeneity in econometric analysis of panel data is usually handled using fixed effects (FE) or random effects (RE) estimators. The main difference between these two estimators is the underlying assumption on the nature of the time-invariant individual effect $\eta_{i}$ in the model with composite error (1). While FE estimator assumes that individual effects are fixed across units (i.e., having nothing in common), RE estimator assumes that individual effects originated from the common probability distribution. In order to get exact evidence which estimator is more appropriate to use, we run

Table 5

Change in harvested surfaces under the wheat (in \%) and annual yield (in $\mathrm{kg}$ / ha) in municipalities up to $100 \mathrm{~m}$.

Source: Jelonik, 2017.

\begin{tabular}{|c|c|c|c|c|c|c|}
\hline Year & Variable & Negotin & Zrenjanin & $\begin{array}{l}\text { Sremska } \\
\text { Mitrovica }\end{array}$ & $\begin{array}{l}\text { Banatski } \\
\text { Karlovac - } \\
\text { Alibunar }\end{array}$ & $\begin{array}{l}\text { Kikinda - } \\
\text { Čoka }\end{array}$ \\
\hline \multirow[t]{2}{*}{2000} & $\Delta \mathrm{P}$ & $0,31 \%$ & $1,39 \%$ & $6,82 \%$ & $-1,97 \%$ & $-9,50 \%$ \\
\hline & $\mathrm{Y}$ & 2.822 & 3.200 & 3.543 & 3.084 & 2.747 \\
\hline \multirow[t]{2}{*}{2001} & $\Delta \mathrm{P}$ & $-0,83 \%$ & $0,04 \%$ & $0,20 \%$ & $2,00 \%$ & $1,54 \%$ \\
\hline & $\mathrm{Y}$ & 3.571 & 4.072 & 4.237 & 3.666 & 3.198 \\
\hline \multirow[t]{2}{*}{2002} & $\Delta \mathrm{P}$ & $-0,26 \%$ & $0,41 \%$ & $-0,63 \%$ & $0,17 \%$ & $0,25 \%$ \\
\hline & $\mathrm{Y}$ & 1.115 & 2.906 & 4.181 & 2.657 & 2.344 \\
\hline \multirow[t]{2}{*}{2003} & $\Delta \mathrm{P}$ & $-1,81 \%$ & $-0,99 \%$ & $-4,94 \%$ & $-3,75 \%$ & $-0,68 \%$ \\
\hline & $\mathrm{Y}$ & 1.917 & 2.154 & 2.917 & 1.826 & 1.356 \\
\hline \multirow[t]{2}{*}{2004} & $\Delta \mathrm{P}$ & $-0,21 \%$ & $-0,44 \%$ & $0,30 \%$ & $-0,38 \%$ & $1,36 \%$ \\
\hline & $\mathrm{Y}$ & 3.937 & 4.876 & 4.959 & 4.131 & 4.448 \\
\hline \multirow[t]{2}{*}{2005} & $\Delta \mathrm{P}$ & $-0,66 \%$ & $-1,20 \%$ & $-3,03 \%$ & $-2,74 \%$ & $-2,50 \%$ \\
\hline & $\mathrm{Y}$ & 3.518 & 4.185 & 4.181 & 3.759 & 3.739 \\
\hline \multirow[t]{2}{*}{2006} & $\Delta \mathrm{P}$ & $0,05 \%$ & $-1,08 \%$ & $-1,12 \%$ & $-0,09 \%$ & $1,35 \%$ \\
\hline & $\mathrm{Y}$ & 2.759 & 3.881 & 4.123 & 3.897 & 2.948 \\
\hline \multirow[t]{2}{*}{2007} & $\Delta \mathrm{P}$ & $-0,62 \%$ & $3,27 \%$ & $1,37 \%$ & $1,05 \%$ & $0,81 \%$ \\
\hline & $\mathrm{Y}$ & 1.400 & 3.917 & 4.038 & 3.335 & 3.104 \\
\hline \multirow[t]{2}{*}{2008} & $\Delta \mathrm{P}$ & $-0,60 \%$ & $-5,27 \%$ & $-3,92 \%$ & $0,70 \%$ & $-5,04 \%$ \\
\hline & $\mathrm{Y}$ & 3.594 & 4.832 & 4.868 & 4.881 & 3.805 \\
\hline \multirow[t]{2}{*}{2009} & $\Delta \mathrm{P}$ & $1,19 \%$ & $4,79 \%$ & $5,37 \%$ & $-0,72 \%$ & $3,47 \%$ \\
\hline & $\mathrm{Y}$ & 3.404 & 3.956 & 4.198 & 4.146 & 2.812 \\
\hline \multirow[t]{2}{*}{2010} & $\Delta \mathrm{P}$ & $-0,52 \%$ & $-4,56 \%$ & $-2,10 \%$ & $-2,50 \%$ & $0,88 \%$ \\
\hline & $\mathrm{Y}$ & 3.036 & 3.795 & 3.604 & 3.768 & 3.425 \\
\hline \multirow[t]{2}{*}{2011} & $\Delta \mathrm{P}$ & $0,43 \%$ & $0,82 \%$ & $-1,31 \%$ & $-1,05 \%$ & $-2,04 \%$ \\
\hline & $\mathrm{Y}$ & 3.574 & 5.043 & 4.267 & 4.155 & 4.652 \\
\hline \multirow[t]{2}{*}{2012} & $\Delta \mathrm{P}$ & $13,29 \%$ & $0,00 \%$ & $1,72 \%$ & $-0,43 \%$ & $5,17 \%$ \\
\hline & $\mathrm{Y}$ & 3.427 & 4.330 & 4.422 & 3.654 & 3.799 \\
\hline \multirow[t]{2}{*}{2013} & $\Delta \mathrm{P}$ & $3,77 \%$ & $3,84 \%$ & $4,90 \%$ & $1,79 \%$ & $2,84 \%$ \\
\hline & $\mathrm{Y}$ & 3.841 & 5.849 & 5.469 & 5.333 & 5.121 \\
\hline
\end{tabular}

$\Delta \mathrm{P}$ - annual change in harvested areas under wheat.

$\mathrm{Y}$ - yield. 
Table 6

Change in harvested surfaces under the wheat (in \%) and annual yield (in $\mathrm{kg}$ ) in municipalities. 100-200 m

Source: Jelonik, 2017.

\begin{tabular}{|c|c|c|c|c|c|}
\hline Year & Variable & Palić-Subotica & Loznica & Ćuprija & Zaječar \\
\hline \multirow[t]{2}{*}{2000} & $\Delta \mathrm{P}$ & $5,27 \%$ & $0,62 \%$ & $1,61 \%$ & $0,30 \%$ \\
\hline & $\mathrm{Y}$ & 2.805 & 3.333 & 2.780 & 2.030 \\
\hline \multirow[t]{2}{*}{2001} & $\Delta \mathrm{P}$ & $-5,07 \%$ & $1,41 \%$ & $1,51 \%$ & $-0,61 \%$ \\
\hline & $\mathrm{Y}$ & 3.464 & 2.809 & 3.765 & 3.273 \\
\hline \multirow[t]{2}{*}{2002} & $\Delta \mathrm{P}$ & $1,91 \%$ & $7,46 \%$ & $-0,78 \%$ & $-0,08 \%$ \\
\hline & $\mathrm{Y}$ & 3.559 & 3.203 & 3.891 & 1.511 \\
\hline \multirow[t]{2}{*}{2003} & $\Delta \mathrm{P}$ & $-2,94 \%$ & $-10,49 \%$ & $0,04 \%$ & $-2,33 \%$ \\
\hline & $\mathrm{Y}$ & 1.586 & 2.347 & 2.579 & 1.934 \\
\hline \multirow[t]{2}{*}{2004} & $\Delta \mathrm{P}$ & $0,59 \%$ & $2,06 \%$ & $2,63 \%$ & $1,06 \%$ \\
\hline & $\mathrm{Y}$ & 4.445 & 3.558 & 4.583 & 3.567 \\
\hline \multirow[t]{2}{*}{2005} & $\Delta \mathrm{P}$ & $-4,26 \%$ & $-1,24 \%$ & $-4,03 \%$ & $-0,23 \%$ \\
\hline & $\mathrm{Y}$ & 4.054 & 3.162 & 3.303 & 3.681 \\
\hline \multirow[t]{2}{*}{2006} & $\Delta \mathrm{P}$ & $1,49 \%$ & $-0,11 \%$ & $-0,07 \%$ & $-1,13 \%$ \\
\hline & $\mathrm{Y}$ & 4.646 & 2.937 & 2.886 & 2.557 \\
\hline \multirow[t]{2}{*}{2007} & $\Delta \mathrm{P}$ & $0,65 \%$ & $-0,25 \%$ & $0,55 \%$ & $0,73 \%$ \\
\hline & $\mathrm{Y}$ & 3.622 & 3.220 & 3.035 & 1.536 \\
\hline \multirow[t]{2}{*}{2008} & $\Delta \mathrm{P}$ & $-1,43 \%$ & $-1,05 \%$ & $-0,06 \%$ & $-1,38 \%$ \\
\hline & $\mathrm{Y}$ & 5.094 & 3.353 & 4.438 & 4.021 \\
\hline \multirow[t]{2}{*}{2009} & $\Delta \mathrm{P}$ & $1,48 \%$ & $0,77 \%$ & $1,38 \%$ & $0,97 \%$ \\
\hline & $\mathrm{Y}$ & 3.695 & 3.230 & 3.952 & 3.226 \\
\hline \multirow[t]{2}{*}{2010} & $\Delta \mathrm{P}$ & $-3,78 \%$ & $-0,63 \%$ & $-3,18 \%$ & $-1,72 \%$ \\
\hline & $\mathrm{Y}$ & 3.613 & 2.567 & 3.669 & 2.899 \\
\hline \multirow[t]{2}{*}{2011} & $\Delta \mathrm{P}$ & $-0,85 \%$ & $-1,36 \%$ & $2,47 \%$ & $0,58 \%$ \\
\hline & $\mathrm{Y}$ & 5.451 & 3.458 & 3.833 & 3.313 \\
\hline \multirow[t]{2}{*}{2012} & $\Delta \mathrm{P}$ & $1,62 \%$ & $3,85 \%$ & $13,46 \%$ & $9,46 \%$ \\
\hline & $\mathrm{Y}$ & 3.949 & 4.005 & 3.685 & 3.389 \\
\hline \multirow[t]{2}{*}{2013} & $\Delta \mathrm{P}$ & $5,07 \%$ & $3,72 \%$ & $0,79 \%$ & $1,28 \%$ \\
\hline & $\mathrm{Y}$ & 5.559 & 3.968 & 4.078 & 3.217 \\
\hline
\end{tabular}

$\Delta \mathrm{P}$ - annual change in harvested areas under wheat.

$\mathrm{Y}$ - yield.

Table 7

Change in harvested surfaces under the wheat (in \%) and annual yield (in $\mathrm{kg}$ ) in municipalities over the $200 \mathrm{~m}$.

Source: Jelonik, 2017.

\begin{tabular}{|c|c|c|c|c|c|c|}
\hline Year & Variable & Kragujevac & Kraljevo & Leskovac & Požega & Vranje \\
\hline \multirow[t]{2}{*}{2000} & $\Delta \mathrm{P}$ & $2,20 \%$ & $0,13 \%$ & $1,37 \%$ & $0,06 \%$ & $-0,28 \%$ \\
\hline & $\mathrm{Y}$ & 2.557 & 2.494 & 2.468 & 2.887 & 1.808 \\
\hline \multirow[t]{2}{*}{2001} & $\Delta \mathrm{P}$ & $0,45 \%$ & $0,22 \%$ & $-0,44 \%$ & $0,03 \%$ & $-0,12 \%$ \\
\hline & $\mathrm{Y}$ & 3.790 & 3.311 & 2.853 & 2.863 & 2.638 \\
\hline \multirow[t]{2}{*}{2002} & $\Delta \mathrm{P}$ & $-0,05 \%$ & $0,09 \%$ & $0,30 \%$ & $-0,37 \%$ & $-0,37 \%$ \\
\hline & $\mathrm{Y}$ & 3.430 & 3.237 & 2.813 & 2.542 & 2.970 \\
\hline \multirow[t]{2}{*}{2003} & $\Delta \mathrm{P}$ & $-0,68 \%$ & $-0,46 \%$ & $-1,21 \%$ & $-0,21 \%$ & $-0,68 \%$ \\
\hline & $\mathrm{Y}$ & 2.153 & 2.320 & 2.387 & 2.323 & 1.913 \\
\hline \multirow[t]{2}{*}{2004} & $\Delta \mathrm{P}$ & $0,90 \%$ & $0,22 \%$ & $0,52 \%$ & $0,20 \%$ & $0,50 \%$ \\
\hline & $\mathrm{Y}$ & 4.156 & 3.845 & 3.667 & 3.396 & 3.462 \\
\hline \multirow[t]{2}{*}{2005} & $\Delta \mathrm{P}$ & $-1,36 \%$ & $-0,60 \%$ & $-0,74 \%$ & $-0,13 \%$ & $-0,18 \%$ \\
\hline & $\mathrm{Y}$ & 2.847 & 3.454 & 2.992 & 3.190 & 2.998 \\
\hline \multirow[t]{2}{*}{2006} & $\Delta \mathrm{P}$ & $-1,81 \%$ & $0,06 \%$ & $-0,30 \%$ & $-0,47 \%$ & $-0,32 \%$ \\
\hline & $\mathrm{Y}$ & 3.127 & 3.594 & 2.880 & 2.919 & 2.799 \\
\hline \multirow[t]{2}{*}{2007} & $\Delta \mathrm{P}$ & $0,34 \%$ & $0,19 \%$ & $-0,46 \%$ & $0,07 \%$ & $-0,23 \%$ \\
\hline & $\mathrm{Y}$ & 3.080 & 3.961 & 2.655 & 2.884 & 2.731 \\
\hline \multirow[t]{2}{*}{2008} & $\Delta \mathrm{P}$ & $-0,88 \%$ & $-0,82 \%$ & $-0,38 \%$ & $-0,51 \%$ & $-0,23 \%$ \\
\hline & $\mathrm{Y}$ & 3.827 & 4.211 & 3.611 & 3.388 & 3.469 \\
\hline \multirow[t]{2}{*}{2009} & $\Delta \mathrm{P}$ & $0,34 \%$ & $0,17 \%$ & $0,01 \%$ & $0,26 \%$ & $-1,72 \%$ \\
\hline & $\mathrm{Y}$ & 3.387 & 3.763 & 2.970 & 2.986 & 2.800 \\
\hline \multirow[t]{2}{*}{2010} & $\Delta \mathrm{P}$ & $-0,63 \%$ & $-0,29 \%$ & $0,47 \%$ & $-0,28 \%$ & $-0,35 \%$ \\
\hline & $\mathrm{Y}$ & 3.224 & 3.243 & 2.529 & 2.712 & 2.803 \\
\hline \multirow[t]{2}{*}{2011} & $\Delta \mathrm{P}$ & $0,23 \%$ & $0,11 \%$ & $0,03 \%$ & $0,01 \%$ & $-0,02 \%$ \\
\hline & $\mathrm{Y}$ & 3.648 & 3.762 & 3.431 & 3.128 & 3.283 \\
\hline \multirow[t]{2}{*}{2012} & $\Delta \mathrm{P}$ & $5,64 \%$ & $2,54 \%$ & $15,97 \%$ & $0,99 \%$ & $11,72 \%$ \\
\hline & $\mathrm{Y}$ & 3.895 & 3.417 & 2.909 & 2.777 & 3.255 \\
\hline \multirow[t]{2}{*}{2013} & $\Delta \mathrm{P}$ & $0,98 \%$ & $0,58 \%$ & $0,34 \%$ & $0,01 \%$ & $0,68 \%$ \\
\hline & $\mathrm{Y}$ & 3.995 & 4.216 & 3.773 & 3.811 & 3.854 \\
\hline
\end{tabular}

$\Delta \mathrm{P}$ - annual change in harvested areas under wheat.

$\mathrm{Y}$ - yield.
Table 8

Estimated Pearson's correlation coefficients between explanatory variables in the model.

\begin{tabular}{lllllll}
\hline Variable & $\mathrm{ff}_{1 \_ \text {avg }}$ & $\mathrm{ff}_{2 \_ \text {avg }}$ & $\mathrm{ff}_{\text {3_avg }}$ & $\mathrm{ff}_{4 \_ \text {avg }}$ & $\mathrm{f}_{0}$ & $\Delta \mathrm{P}$ \\
\hline $\mathrm{ff}_{1_{\text {_avg }}}$ & 1 & & & & & \\
$\mathrm{ff}_{2 \text { _avg }}$ & 0.6035 & 1 & & & & \\
$\mathrm{ff}_{3 \text { _avg }}$ & 0.0659 & 0.1829 & 1 & & & \\
$\mathrm{ff}_{4}$ avg & -0.0527 & 0.0931 & 0.6784 & 1 & & \\
$\mathrm{f}_{0}$ & -0.7956 & -0.4326 & -0.0016 & -0.0225 & 1 & \\
$\Delta \mathrm{P}$ & 0.3779 & 0.2148 & 0.0723 & 0.0323 & -0.3479 & 1 \\
\hline
\end{tabular}

$\mathrm{f}_{0}$ - planting day.

$\mathrm{ff}_{1}-\mathrm{ff}_{4}-$ subperiods

$\Delta \mathrm{P}$ - annual change in harvested areas under wheat.

$\mathrm{Y}$ - yield.

Note: Pearson correlation coefficient measures level of co-variations between two numeric variables, in percentage.

Table 9

Collinearity diagnostic for explanatory variables in the model.

\begin{tabular}{lll}
\hline Variable & \multicolumn{2}{l}{ Collinearity Statistics } \\
\cline { 2 - 3 } & Tolerance & VIF \\
\hline $\mathrm{ff}_{1 \_ \text {avg }}$ & .258 & 3.871 \\
$\mathrm{ff}_{2 \_ \text {avg }}$ & .608 & 1.646 \\
$\mathrm{ff}_{3 \_ \text {avg }}$ & .501 & 1.997 \\
$\mathrm{ff}_{4}$ aavg & .501 & 1.997 \\
$\mathrm{f}_{0}$ & .340 & 2.940 \\
$\Delta \mathrm{P}$ & .848 & 1.180 \\
\hline
\end{tabular}

$\mathrm{f}_{0}$ - planting day.

$\mathrm{ff}_{1}-\mathrm{ff}_{4}-$ subperiods.

$\Delta \mathrm{P}$ - annual change in harvest areas under wheat.

Note: Tolerance measures level of variations of given explanatory variables which can not be explained by variations of other explanatory variables in the model.

Hausman (1978) test, first assuming that the variance-covariance matrices are based on the estimated disturbance variance from the consistent estimator (FE) and then from the efficient estimator (RE). In both cases, the Hausman test suggests that RE is more appropriate to use, as shown in the Table 10.

By evaluating the model (Eq. (1) using the estimator of random effects, the detrimental effect of unobserved heterogeneity on the reliability of regression assessment is significantly reduced. Since there is a high probability of having heteroscedasticity in the given set of data, we also applied Huber-White estimator of heteroscedasticity-consistent standard errors within RE estimation. This improves the reliability of correct inferences about the statistical significance of the estimated coefficients.

Before econometric estimation, we apply a unit root test to check the stationarity of the data. As Birkel (2014) noticed, non-stationarity of panel data can result in multiple estimation issues: conventional estimation technics produce consistent parameter estimates only under particular circumstances, conventional estimates for standard errors do not allow valid inference and properties of estimators are dependent on cointegration. To test the presence of non-stationarity, we use two forms of panel unit root tests: a) Levin-Lin-Chu test (LLC) and b) ImPesaran-Shin (IPS). LLC test assumes that all panels follow the common autoregressive process, while the IPS test is based on the more realistic assumption, that each panel follows its autoregressive process. Results of panel unit root tests are presented in Table 11.

As seen from the table, almost all variables used in regressions are stationary according to both tests, at a significance level of $1 \%$. The only exemption is an annual change in harvested areas under wheat $(\Delta \mathrm{P})$ in case of LLC, but more reliable IPS test suggests that this variable is stationary, too. 
Table 10

Hausman test for choice between Random and Fixed Effects estimator.

\begin{tabular}{|c|c|c|}
\hline Variance-covariance matrices base & Estimated disturbance variance from the consistent (FE) estimator & Estimated disturbance variance from the efficient (RE) estimator \\
\hline Test statistic (chi squared) & 7.17 & 7.13 \\
\hline P-value & 0.3054 & 0.3093 \\
\hline
\end{tabular}

Note: H0 - "Individual effects are adequately modeled by a random effects model".

Table 11

Panel unit root tests for all variables in the model.

\begin{tabular}{lll}
\hline Variable & LLC test & IPS test \\
\hline $\mathrm{Y}$ & $-5.27^{* * *}$ & $-4.63^{* * *}$ \\
$\mathrm{ff}_{1 \_ \text {avg }}$ & $-2.42^{* * *}$ & $-5.88^{* * *}$ \\
$\mathrm{ff}_{2 \_ \text {avg }}$ & $-13.47^{* * *}$ & $-5.65^{* * *}$ \\
$\mathrm{ff}_{3 \text { _avg }}$ & $-7.75^{* * *}$ & $-6.30^{* * *}$ \\
$\mathrm{ff}_{4 \_ \text {avg }}$ & $-8.22^{* * *}$ & $-6.67^{* * *}$ \\
$\mathrm{f}_{0}$ & $-2.57^{* * *}$ & $-6.52^{* * *}$ \\
$\Delta \mathrm{P}$ & 0.05 & $-7.01^{* * *}$ \\
\hline
\end{tabular}

$\mathrm{f}_{0}$ - planting day.

$\mathrm{ff}_{1}-\mathrm{ff}_{4}-$ subperiods.

$\Delta \mathrm{P}$ - annual change in harvest areas under wheat.

Note: standard errors in brackets; level of significance: * $\mathrm{p}<0.1$, ${ }^{* *} \mathrm{p}<0.05$, $* * * \mathrm{p}<0.01$.

HO - "Panels contain unit roots" for both tests.

H1 - "Panels are stationary" for LLC, "Some panels are stationary" for IPS.

The results of the regression model estimation (Eq. (1)) for the yield of wheat are shown in Table 12, where columns 1-4 show the results of the estimation of the random effect model by gradual extension of regression specification, while the last column shows the results of the pooled model's estimation. The gradual extension of regression specification allows monitoring of the marginal changes in the value of the regression coefficients and the coefficient of determinations and thus indicate the robustness of the estimation results.

The second part of the analysis included the estimation of the model of random effects on sub-samples (grouping of municipalities by altitude), (Table 13).

The previously discussed conceptual limitations imply that variables used in the model are most likely subject to measurement errors. Similar to unobserved heterogeneity, measurement error is a typical pitfall of non-experimental research and source of model endogeneity, which may compromise the estimation results (Antonakis et al., 2014). The model endogeneity caused by measurement errors is often addressed using non-standard estimation methods, such as the two-stage least-squares method or the generalized method of moments. Both of these procedures require the use of instrumental variables, which have two properties: high correlation with explanatory variables of interest and no correlation with random error. Because there was no possibility to identify adequate natural instruments due to the specific nature of this research, we consider Wald's, Bartlett's and Durbin's method of grouping observations of existing explanatory variables to create new instrumental variables that satisfy required properties (Gillard, 2010). Since the water scarcity in the phenophases 2 and soil moisture saturation on the supposed day of planting are two weather factors with the most persistent impact on wheat yield, we instrumentalized both of them using all available methods of grouping. The model is re-estimated using the two-stage least-squares method and random effect estimator. The results of regression estimation using instrumental variables approach, presented in Table 14, confirm the stability of estimated parameters even in the case when potential endogeneity from measurement errors is tackled.

Table 12

Econometric estimation of gradually extended model by Random Effects estimator and full model by Pooled OLS estimator, for the total sample of municipalities.

\begin{tabular}{|c|c|c|c|c|c|}
\hline \multirow[t]{2}{*}{ Variable } & \multicolumn{4}{|c|}{ Random effects } & \multirow[t]{2}{*}{ Pooled } \\
\hline & 1 & 2 & 3 & 4 & \\
\hline $\mathrm{ff}_{2 \_ \text {avg }}$ & $\begin{array}{l}-2604.7627^{* * *} \\
(432.1977)\end{array}$ & $\begin{array}{l}-2102.5805^{* * *} \\
(312.4325)\end{array}$ & $\begin{array}{l}-1793.4160^{* * *} \\
(308.0658)\end{array}$ & $\begin{array}{l}-1750.5763^{* * *} \\
(304.5088)\end{array}$ & $\begin{array}{l}-2103.3754^{* * *} \\
(444.5704)\end{array}$ \\
\hline $\mathrm{ff}_{\text {3_avg }}$ & & $\begin{array}{l}-635.8655^{* * *} \\
(104.9991)\end{array}$ & $\begin{array}{l}-631.5058^{* * *} \\
(106.1071)\end{array}$ & $\begin{array}{l}-449.1062^{* * *} \\
(107.5404)\end{array}$ & $\begin{array}{l}-1424.0514^{* * *} \\
(349.5853)\end{array}$ \\
\hline $\mathrm{ff}_{1 \_ \text {avg }}$ & & & $\begin{array}{l}-341.4279^{* * *} \\
(127.184)\end{array}$ & $\begin{array}{l}-488.9886^{* * *} \\
(153.6249)\end{array}$ & $\begin{array}{l}-335.1038 \\
(13.7007)\end{array}$ \\
\hline $\mathrm{ff}_{4 \_ \text {avg }}$ & & & & $\begin{array}{l}-148.0775^{* *} \\
(70.0957)\end{array}$ & $\begin{array}{l}-177.9797 * * \\
(123.8719)\end{array}$ \\
\hline $\mathrm{f}_{0}$ & $\begin{array}{l}-1265.7553^{* * *} \\
(163.4748)\end{array}$ & $\begin{array}{l}-1037.8192^{* * *} \\
(170.251)\end{array}$ & $\begin{array}{l}-1370.6377^{* * *} \\
(218.6377)\end{array}$ & $\begin{array}{l}-1528.3348^{* * *} \\
(196.8302)\end{array}$ & $\begin{array}{l}-335.7365 \\
(236.4925)\end{array}$ \\
\hline$\Delta \mathrm{P}$ & $\begin{array}{l}36.0720 * * * \\
(11.5096)\end{array}$ & $\begin{array}{l}45.4019 * * * \\
(13.73)\end{array}$ & $\begin{array}{l}48.6888 * * * \\
(14.2737)\end{array}$ & $\begin{array}{l}48.9096 * * * \\
(15.1153)\end{array}$ & $\begin{array}{l}-172.9308^{* *} \\
(76.8037)\end{array}$ \\
\hline Alt & & & & & $\begin{array}{l}-290.8344^{* * *} \\
-44.3237\end{array}$ \\
\hline Const & $\begin{array}{l}4447.9850 * * * \\
(190.2482)\end{array}$ & $\begin{array}{l}4980.2385^{* * *} \\
(228.2351)\end{array}$ & $\begin{array}{l}5303.5067^{* * *} \\
(313.4955)\end{array}$ & $\begin{array}{l}5638.6563^{* * *} \\
(357.5839)\end{array}$ & $\begin{array}{l}6171.9362^{* * *} \\
(329.583)\end{array}$ \\
\hline R Sq & 0.43 & 0.56 & 0.57 & 0.58 & 0.42 \\
\hline
\end{tabular}

$\mathrm{f}_{0}$ - planting day.

$\mathrm{ff}_{1}-\mathrm{ff}_{4}-$ subperiods.

$\Delta \mathrm{P}$ - annual change in harvest areas under wheat.

Alt - altitude.

Const - Constant.

R sq - R squared.

Note: standard errors in brackets; level of significance: ${ }^{*} \mathrm{p}<0.1,{ }^{* *} \mathrm{p}<0.05$, $* * * \mathrm{p}<0.01$.

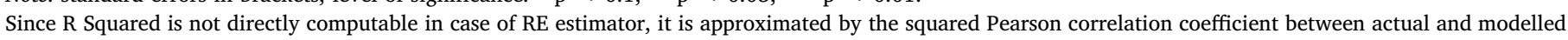
values of dependent variable. 


\section{Discussion}

Research conducted in Kenya for 18 years shows a correlation between weather factors and yields, and linear regression pointed out that wheat yield is statistically highly dependent on several weather factors. That includes precipitation, temperature, and humidity. However, the author did not test causality (Nderitu, 2016).

Research on the production of spring wheat in Canada during the 24 years, confirms the correlation of the yields and weather factors as well. Moreover, the authors have provided the following empirical evidence. An increase in the number of days with extremely high temperature by $20 \%$ decreases average yields by $11.7 \mathrm{~kg} / \mathrm{ha}$ for spring wheat (Meng et al., 2017).

In the previous research, authors have analyzed the influence of weather factors on maize yields in Serbia. Results have shown that temperature growth for $1{ }^{\circ} \mathrm{C}$ during the days in which temperature exceeds $30{ }^{\circ} \mathrm{C}$, can cause a decrease in yield by almost $10 \mathrm{~kg} / \mathrm{ha}$ and daily increase in water deficit by $1 \mathrm{~mm}$ can lead to yield reduction for more than $340 \mathrm{~kg} / \mathrm{ha}$. The results confirmed that weather factors do not have a statistically significant impact on yields at the altitudes above $200 \mathrm{~m}$ (Zubović et al., 2017).

In comparison, our results show that there is a strong dominance of the water scarcity in the sub-periods 2 and 3, as explanatory variables with the greatest intensity, significance, and robustness, while other explanatory variables, although predominantly significant, minimally contribute to the increase in the explanatory power of the model. The increase in the average daily water scarcity of $0.1 \mathrm{~mm}$ in phenophase 2 reduces the yield by more than $175 \mathrm{~kg} / \mathrm{ha}$ and about $45 \mathrm{~kg} / \mathrm{ha}$ in phenophase 3. Statistical significance of the effect of soil moisture saturation on the day of planting with a markedly negative impact on wheat yield is evident. Changes in harvested areas under wheat in total arable land have a very positive impact on the growth of wheat yield. Therefore the marginal increment of wheat areas is mainly carried out

Table 13

Econometric estimation of full model for each subsample of municipalities, by Random Effects estimator.

\begin{tabular}{|c|c|c|c|}
\hline \multirow[t]{2}{*}{ Variable } & \multicolumn{3}{|c|}{ Random effects } \\
\hline & Alt1 & Alt2 & Alt3 \\
\hline $\mathrm{ff}_{2 \_ \text {avg }}$ & $\begin{array}{l}-3057.8019 * * * \\
(493.0989)\end{array}$ & $\begin{array}{l}-1794.3879 * * * \\
(403.0284)\end{array}$ & $\begin{array}{l}-820.3836 \\
(622.4601)\end{array}$ \\
\hline $\mathrm{ff}_{3 \_ \text {avg }}$ & $\begin{array}{l}-728.1522^{* * *} \\
(151.4551)\end{array}$ & $\begin{array}{l}-196.8755 \\
(237.645)\end{array}$ & $\begin{array}{l}-189.5869^{*} \\
(110.3371)\end{array}$ \\
\hline $\mathrm{ff}_{\mathbf{1}_{-} \text {avg }}$ & $\begin{array}{l}-69.6693 \\
(448.3952)\end{array}$ & $\begin{array}{l}-918.6832^{*} \\
(491.6471)\end{array}$ & $\begin{array}{l}-321.3239 \\
(217.3961)\end{array}$ \\
\hline $\mathrm{ff}_{\mathbf{H}_{-} \text {avg }}$ & $\begin{array}{l}-91.4832 \\
(91.8951)\end{array}$ & $\begin{array}{l}-260.1866 \\
(223.8466)\end{array}$ & $\begin{array}{l}-219.1990 * * \\
(101.645)\end{array}$ \\
\hline$f_{0}$ & $\begin{array}{l}-1155.8621 * \\
(700.3312)\end{array}$ & $\begin{array}{l}-1985.7989 * * * \\
(567.5964)\end{array}$ & $\begin{array}{l}-1362.8579^{* * *} \\
(310.7278)\end{array}$ \\
\hline$\Delta \mathbf{P}$ & $\begin{array}{l}57.8577^{* * * *} \\
(16.0492)\end{array}$ & $\begin{array}{l}49.6667 \\
(32.6167)\end{array}$ & $\begin{array}{l}20.5296 \\
(21.9716)\end{array}$ \\
\hline Const & $\begin{array}{l}5873.7194 * * * \\
(689.6182)\end{array}$ & $\begin{array}{l}6121.3335^{* * *} \\
(960.1427)\end{array}$ & $\begin{array}{l}4962.1371^{* * *} \\
(350.1317)\end{array}$ \\
\hline R Sq & 0.43 & 0.40 & 0.33 \\
\hline No of obs. & 70 & 56 & 70 \\
\hline
\end{tabular}

$\mathrm{f}_{0}$ - planting day.

$\mathrm{ff}_{1}-\mathrm{ff}_{4}-$ subperiods.

$\Delta \mathrm{P}$ - annual change in harvest areas under wheat.

Alt - altitude.

Const - Constant.

$\mathrm{R}$ sq - R squared.

No of obs. - Number of observations.

Note: standard errors in brackets; level of significance: ${ }^{*} \mathrm{p}<0.1$, ${ }^{* *} \mathrm{p}<0.05$, $* * * \mathrm{p}<0.01$.

Since R Squared is not directly computable in case of RE estimator, it is approximated by the squared Pearson correlation coefficient between actual and modelled values of dependent variable. on a better-quality soil, which ultimately results in a higher average yield. The regression coefficients obtained by estimating the pooled model corresponds with the estimation of the model with random effects, while the altitude has a significant negative impact on the yield of wheat.

The results of the estimation (Table 13) imply that the water scarcity in the phenophases 2 and 3 has a significant effect only in the lowlands, while with an increase in altitude above $100 \mathrm{~m}$ the effect is rapidly decreasing. Similarly, changes in the areas under wheat make the effect lose intensity and significance with the increase in altitude, which is expected, given that the availability of high-quality agricultural land at higher altitudes is reduced. The specific curiosity of the estimation is a confirmation of the robustness of the extremely negative impact of soil moisture saturation on the supposed day of planting, which manifests itself at higher and lower altitudes as well as on the entire sample.

\section{Conclusions}

In order to test the statistical significance of the impact of the weather factors on yields, we used a data panel with data on weather conditions, altitude, wheat yields and share of land under wheat in total utilized agricultural land on a specific territorial unit. A multidimensional regression for fourteen municipalities in Serbia for fourteen years, harmonized with the Hargreaves method of determining reference evapotranspiration has been performed.

The results confirm that an increase in the average daily water scarcity ( $\Delta$ ET) by $0.1 \mathrm{~mm}$ in sub-periods II (November 15th -April 1st) and III (April 1st -May 15th) initiates a potential reduction in yields of about $175 \mathrm{~kg} / \mathrm{ha}$ and over $45 \mathrm{~kg} / \mathrm{ha}$ respectively. Moreover, water scarcity has a significant effect on wheat yield only in the plain regions, which with the rise of the altitude above $100 \mathrm{~m}$ rapidly loses its intensity and significance.

Results show with a high statistical significance that change in weather conditions observed through variations in precipitation and

\section{Table 14}

Econometric estimation of the full model by instrumental variables approach, for the total sample of municipalities.

\begin{tabular}{llll}
\hline Variable & \multicolumn{3}{c}{ Random effects } \\
\cline { 2 - 4 } & Wald & Bartlett & Durbin \\
\hline $\mathrm{ff}_{2 \_ \text {avg }}$ & $-1541.7641^{*}$ & $-1727.7214^{* * *}$ & $-1463.8228^{* * *}$ \\
$\mathrm{ff}_{\text {3_avg }}$ & $(838.3563)$ & $(729.2323)$ & $(629.5273)$ \\
$\mathrm{ff}_{1 \_ \text {avg }}$ & $-447.9505^{* * *}$ & $-470.3919^{* * *}$ & $-471.5961^{* * *}$ \\
& $(127.2834)$ & $(124.2541)$ & $(121.8768)$ \\
$\mathrm{ff}_{4 \_ \text {avg }}$ & -586.0712 & -391.3046 & -482.5897 \\
& $(440.5011)$ & $(353.3202)$ & $(301.5519)$ \\
$\mathrm{f}_{0}$ & $-151.5509^{* *}$ & $-138.2612^{* *}$ & $-141.4341^{* * *}$ \\
& $(70.8749)$ & $(68.9038)$ & $(67.8455)$ \\
$\Delta \mathrm{P}$ & $-1626.9988^{* * *}$ & $-1331.6704^{* * *}$ & $-1395.7583^{* * *}$ \\
& $(596.1523)$ & $(469.0052)$ & $(379.6692)$ \\
Const & $48.8799^{* * *}$ & $50.0005^{* * *}$ & $49.9966^{* * *}$ \\
$\mathrm{R} \mathrm{Sq}$ & $(14.7623)$ & $(14.6999)$ & $(14.6645)$ \\
& $5726.3029^{* * *}$ & $5472.1811^{* * *}$ & $5532.1758^{* * *}$ \\
& $(547.2501)$ & $(445.4415)$ & $(378.0676)$ \\
& 0.58 & 0.58 & 0.58 \\
\hline
\end{tabular}

$\mathrm{f}_{0}$ - planting day.

$\mathrm{ff}_{1}-\mathrm{ff}_{4}$ - subperiods.

$\Delta \mathrm{P}$ - annual change in harvest areas under wheat.

Alt - altitude.

Const - Constant.

R sq - R squared.

Note: standard errors in brackets; level of significance: ${ }^{*} \mathrm{p}<0.1$, ${ }^{* *} \mathrm{p}<0.05$, $* * * \mathrm{p}<0.01$.

Since R Squared is not directly computable in case of RE estimator, it is approximated by the squared Pearson correlation coefficient between actual and modelled values of dependent variable. 
temperature increase has a significant impact on wheat yields in Serbia. It is, therefore, recommendable to improve and expand irrigation systems, with the possibility of redistribution of its use only in the second and third subperiods so that they can be moved to other crops in the remaining part of the year.

\section{References}

Antonakis, J., Bendahan, S., Jacquart, P., Lalive, R., 2014. Causality and endogeneity: problems and solutions. In: Day, D.V. (Ed.), The Oxford Handbook of Leadership and Organizations. Oxford University Press, New York, pp. 93-117.

Bezdan, A., Draginčić, J., Pejić, B., Blagojević, B., Mesaroš, M., 2017. Evaluation of reference evapotranspiration methods in the area of the meteorological station Rimski Sancevi. Ann. Agron. 41 (2), 61-67.

Birkel, C., 2014. The analysis of non-stationary pooled time-series cross-section-data. Int. J. Conflict Violence (IJCV) 8 (2), 222-242.

Buck-Sorlin, G., 2013. Process-based model. In: Dubitzky, W., Wolkenhauer, O., Cho, K.H., Yokota, H. (Eds.), Encyclopaedia of Systems Biology. Springer, New York, USA, pp. 1755.

Cannata, M., Antonović, M., 2015. Sensor observations service for environmentally optimizing irrigation: istSOS within the ENORASIS example. Int. J. Geoinformatics Geol. Sci. 11 (3), 1-8.

Challinor, A.J., Müller, C., Asseng, S., Deva, C., Nicklin, K.J., Wallach, D., et al., 2018. Improving the use of crop models for risk assessment and climate change adaptation. Agric. Syst. 159, 296-306.

Chatzikostas, G., Boskidis, I., Symeonidis, P., Tekes, S., Pekakis, P., 2013. In: In: Enorasis Salampasis, M., Theodoridis, A. (Eds.), Procedia Technology, vol. 8. HAICTA 2013, Elsevier Ltd., Amsterdam, the Netherlands, pp. 516-519. available at www. sciencedirect.com/science/article/pii/S2212017313001321.

Craney, T.A., Surles, J.G., 2002. Model-dependent variance inflation factor cutoff values. Qual. Eng. 14 (3), 391-403.

Đorđević, V., Sarić, M., Borojević, S., Đokić, A., Miladinović, N., Šuput, M., et al., 1965. Pšenica. Zadružna knjiga, Beograd, Srbija, pp. 426.

Dragović, S., 2012. Effect of irrigation on field crops yields under the variable agro-climatic conditions of Serbia. Agric. For. 54 (1-4), 25-40.

Gillard, J., 2010. An overview of linear structural models in errors in variables regression. REVSTAT-Stat. J. 8 (1), 57-80.

Glamočlija, Đ., 2012. Posebno Ratarstvo: Žita I Zrnene Mahunarke. Poljoprivredni Fakultet, Beograd, Srbija, pp. 374.

Hargreaves, G., Samani, Z., 1984. Economic considerations of deficit irrigation. J. Irrig. Drain. Eng. 110 (4), 343-358.

Hausman, J.A., 1978. Specification tests in econometrics. Econometrica 46 (6), 1251-1271.

IAE, 2016. General Conditions and Technological-time Frame in Production of Mercantile Winter Wheat Characteristic for the Territory of the Republic of Serbia. Internal documentation, data obtained throughout the in-depth interview with the representatives of the Faculty of Agriculture, University of Belgrade, Serbia and Institute Tamiš, Pančevo, Serbia date of interview, $15^{\text {th }}$ September, 2016, Institute of Agricultural Economics (IAE), Belgrade, Serbia.

Jelonik, M., 2017. Economic Instruments for Climate Risks Management in Crop Production in the Republic of Serbia. Doctoral dissertation. Faculty of Agriculture, University of Novi Sad, Novi Sad, Serbia, pp. 402.

Jelonik, M., Zubović, J., Zdravković, A., 2017. Procena šteta u proizvodnji pšenice izazvanih klimatskim faktorom. Ecologica 24 (87), 501-506.

Jevtić, S., 1977. Pšenica. Nolit, Beograd, Srbija, pp. 531.

Kang, Y., Khan, S., Ma, X., 2009. Climate change impacts on crop yield, crop water productivity, and food security - a review. Prog. Nat. Sci. 19, 1665-1674.

Kljajić, N., Vuković, P., Arsić, S., 2013. The current state of irrigation in the Republic of Serbia. In: Andrei, J.V., Turek, A., Subić, J., Dusmanescu, D. (Eds.), Sustainable Technologies, Policies, and Constraints in the Green Economy. IGI Global, Hershey, USA, pp. 123-139.

Klocke, N.L., Currie, R.S., Tomsicek, D.J., Koehn, J., 2011. Corn yield response to deficit irrigation. Trans. ASABE 54 (3), 931-940.

Kresović, B., Matović, G., Gregorić, E., Djuričin, S., Bodroža, D., 2014. Irrigation as a climate change impact mitigation measure: an agronomic and economic assessment of maize production in Serbia. Agric. Water Manag. 139, 7-16.

Kresović, B., Gajić, B., Tapanarova, A., Pejić, B., Dragović, S., Dragović, R., 2016. Uticaj režima navodnjavanja na prinos i komponente prinosa soje. J. Agric. Sci. 61 (4), 305-321.

Lee, J.H., Kim, C.J., 2013. A multi-model assessment of the climate change effect on the drought severity-duration-frequency relationship. Hydrol. Process. 27 (19), 2800-2813. https://doi.org/10.1002/hyp.9390.

Maksimović, L., Dragović, S., 2002. Effect of sugar beet irrigation in different environmental growing conditions. Field Veg. Crops Res. 36, 43-56.

Maksimović, L., Dragović, S., 2004. Water requirements of field crops and effects of irrigation. Acta Biol. Iugoslavica - serija A: Zemljište i biljka 53 (2), 85-92.

Meng, T., Carew, R., Florkowski, W., Klepacka, A., 2017. Analyzing temperature and precipitation influences on yield distributions of canola and spring wheat in Saskatchewan. J. Appl. Meteorol. Climatol. 56 (4), 897-913.

Mihailović, D.T., Lalić, B., Malinović, S., Arsenić, I., 2004. The use of climate model for purposes of field and vegetable crops production. Field Veg. Crops Res. 40, 35-44.

Moore, F.C., Baldos, U.L.C., Hertel, T., 2017. Economic impacts of climate change on agriculture: a comparison of process-based and statistical yield models. Environ. Res. Lett. 12 (6), 1-9.

Munćan, M., 2016. The impact of mineral fertilization and atmospheric precipitation on the yield of field crops on family farms. Ekon. Poljopr. 63 (3), 817-833.

Nderitu, W.S., 2016. Effects of Rainfall and Temperature Variability on Wheat Production in Narok County. Project Report. available at. University of Nairobi, Department of Meteorology, Nairobi, Kenya, pp. 36. http://meteorology.uonbi.ac.ke/sites/default/ files/cbps/sps/meteorology/WANG\%27OMBE-PROJECT.pdf.

Nelson, G.C., Shively, G.E., 2014. Modeling climate change and agriculture: an in troduction to the special issue. Agric. Econ. 45 (1), 1-2.

Pavlović, P., Kostić, N., Karadžić, B., Mitrović, M., 2017. The Soils of Serbia. World Soils Book Series. Springer Science + Business Media B.V., Dordrecht, the Netherlands, pp. 225.

Pejić, B., Bošnjak, Đ., Mačkić, K., Rajić, M., Josipović, M., Jug, I., Maksimović, L., 2012 Yield and water use efficiency of irrigated soybean in Vojvodina, Serbia. Ratarstvo i povrtarstvo 49 (1), 80-85.

Powell, J.P., Reinhard, S., 2016. Measuring the effects of extreme weather events on yields. Weather Clim. Extrem. 12, 69-79.

Ratknić, T., Milovanović, J., Rarknić, M., Šekularac, G., Subić, J., Jelonik, M., Poduška, Z., 2017. Analysis of the profitability of the restitution of fire-affected beech forests in Serbia. Appl. Ecol. Environ. Res. 15 (4), 1999-2010.

RHSS, 2016. Determination of Referent Evapotranspiration by Hargreaves Method. available at:. Republic Hydro-Meteorological Service of Serbia, Belgrade, Serbia. www.hidmet.gov.rs/latin/meteorologija/agro evapotranspiracija.php.

Slingo, J., Bates, K., Nikiforakis, N., Piggott, M., Roberts, M., Shaffrey, L., ... Weller, P.L., 2009. Developing the next-generation climate system models: challenges and achievements. Philos. Trans. Math. Phys. Eng. Sci. 367, 815-831.

Stričević, R., Đurović, N., Vuković, A., Vujadinović, M., Ćosić, M., Pejić, B., 2014. Procena prinosa i potrebe šećerne repe za vodom u uslovima klimatskih promena na području Republike Srbije primenom AquaCrop modela. J. Agric. Sci. 59 (3), 301-317.

Stute, M., Clement, A., Lohmann, G., 2001. Global climate models: past, present, and future. Proc. Natl. Acad. Sci. 98 (19), 10529-10530.

Tozer, C.R., Verdon Kidd, D.C., Kiem, A.S., 2014. Temporal and spatial variability of the cropping limit in South Australia. Clim. Res. 60, 25-34.

Trajković, S., 2009. Metode proračuna potreba za vodom u navodnjavanju. Univerzitet u Nišu, Građevinsko-arhitektonski fakultet, Niš, Srbija, pp. 100.

Vidal, J.P., Wade, S., 2009. A multimodel assessment of future climatological droughts in the United Kingdom. Int. J. Climatol. 29 (14), 2056-2071. https://doi.org/10.1002/ joc. 1843.

Zubović, J., Jelonik, M., Zdravković, A., Subić, J., Radovanović, S., 2017. Using spatial and seasonal panel model to determine impact of climatic factors on maize yields in Serbia. Rom. Biotechnol. Lett. https://doi.org/10.26327/RBL2017.11. ahead of print, available at. 